\title{
PODERES NÃO SÃO INDEPENDENTES SEM AUTONOMIA FINANCEIRA
}

Coluna publicada em 27.8.2013: <http://www.conjur.com.br/2013-ago-27/ contas-vista-poderes-nao-sao-independentes-autonomia-financeira $>$

O governo federal deve apresentar até o final desta semana a proposta de orçamento para 2014 , obedecendo ao prazo previsto no artigo $35, \$ 2^{\circ}$, do Ato das Disposições Transitórias da Constituição. Trata-se de um ato extremamente importante para toda a sociedade, para o qual todos devem voltar suas atenções uma vez que é na lei orçamentária que se define precisamente o que o governo vai fazer, quanto, como e onde vai gastar o dinheiro que é de todos nós.

Há muitas questôes importantes que se definem neste momento. Desta vez, destacarei apenas uma delas, que é a do respeito à autonomia financeira dos Poderes, em especial do Judiciário, e das instituições também contempladas pela Constituição com maior autonomia sobre seus orçamentos - caso do Ministério Público e Defensoria Pública. Faço isso porque a questão pode voltar ao noticiário nestes próximos dias, como já tem ocorrido há muitos anos, como consequência de embates entre os poderes decorrentes do desrespeito à autonomia financeira que se tem constatado por ocasião da apresentação da proposta orçamentária da União. ${ }^{1}$

Escrevo a respeito de assunto sobre o qual já discorri longamente ${ }^{2}$ e, desta vez, cuidarei dele de modo mais sucinto, deixando ao leitor que tenha interesse mais específico a indicação desta fonte com informações mais completas.

1 Que, como já mencionado, deverá ocorrer até o final desta semana. Na maior parte dos estados, a apresentação proposta orçamentária ocorre no final de setembro, na forma prevista em legislação específica de cada um.

2 CONTI, José Mauricio. A autonomia financeira do Poder Judiciário. São Paulo: MP Editora, 2006, 223p. 
A Constituição assegura, logo no artigo $2^{\circ}$, a independência dos três Poderes - Legislativo, Executivo e Judiciário. A independência pressupõe autonomia, e esta tem em seu aspecto financeiro o pilar mais importante. Não há independência sem autonomia financeira. Isso vale para os Poderes da República, entes da Federação, países e até mesmo para cada um de nós.

Por essa razão é que a Constituição volta a tratar do tema, de forma precisa e detalhada, no artigo 99 assegurando ao Poder Judiciário autonomia administrativa e financeira.

Há que se lembrar estarem as finanças públicas do Estado sob controle conjunto dos Poderes Executivo e Legislativo, que dividem as atribuições nesta matéria. De forma sucinta, vê-se que esta competência da mais alta relevância política é partilhada entre esses dois Poderes de forma razoavelmente equitativa. O Poder Executivo tem a iniciativa das leis orçamentárias, principal instrumento das finanças públicas, que são submetidas ao Poder Legislativo, a quem cabe propor emendas e aprovar o texto final. A execução orçamentária é uma atividade essencialmente comandada pelo Poder Executivo, enquanto a fiscalização financeira e orçamentária é de titularidade do Poder Legislativo.

O Poder Judiciário e demais instituições independentes ficam praticamente excluídos desse processo, o que os fragiliza bastante em matéria de finanças públicas. Daí porque a necessidade que lhes sejam dadas garantias para se fazer respeitar a imprescindível autonomia financeira, sem a qual não se concretiza a independência de poderes assegurada pelo artigo $2^{\circ}$ de nossa Constituição. Justificam-se, pois, dispositivos constitucionais específicos como é o caso do artigo 99, com referência ao Poder Judiciário, artigo 127, $\$ 3^{\circ}$, no que tange ao Ministério Público, e o artigo $134, \$ \$ 2^{\circ}$ e $3^{\circ}$, para a Defensoria Pública. ${ }^{3}$

Entre as várias garantias que se verificam no artigo 99 da Constituição, a mais relevante é aquela contida no $₫ 1^{\circ}$, segundo o qual "os tribunais elaborarão suas propostas orçamentárias dentro dos limites estipulados conjuntamente com os demais Poderes na lei de diretrizes orçamentárias". ${ }^{4}$

Embora a lei orçamentária seja de iniciativa privativa e vinculada do Poder Executivo, cabe ao Judiciário estipular a parcela do orçamento que prevê seus

3 E não se deve esquecer os Tribunais de Contas, instituições fundamentais para a fiscalização das contas públicas, para o que devem ser independentes, tendo o texto constitucional lhes assegurado, em vários dispositivos, garantias voltadas a preservar sua independência funcional.

4 No mesmo sentido dispõe os artigos anteriormente citados, referindo-se ao Ministério Público e à Defensoria Pública. 
próprios gastos. Não pode haver interferência do Executivo, uma vez que os limites dentro dos quais deva ser apresentada estão previamente fixados na lei de diretrizes orçamentárias, aprovada pelo Poder Legislativo, e que antecede (ou deveria anteceder...) a apresentação da proposta de orçamento.

Infelizmente esse dispositivo constitucional não vem sendo cumprido da forma como se espera. Muitos entes da federação - entre os quais, o estado mais rico da Federação, que é São Paulo - sequer fazem constar o limite de despesas do Poder Judiciário na lei de diretrizes orçamentárias, deixando um vácuo legislativo inaceitável, pois não estabelece os parâmetros para a apresentação da proposta por parte do Poder Judiciário, que fica, por conseguinte, livre para apresentar o orçamento da forma que entende adequada. Essa proposta, por sua vez, ao ser incorporada ao projeto de lei orçamentária do Estado, tem sofrido "cortes" em seus valores, promovidos pelo Poder Executivo de forma absolutamente inconstitucional, 5 em flagrante afronta à autonomia financeira do Poder Judiciário, fato que é recorrente nesse período todos os anos, esperando-se que neste venha a ser uma exceção.

Mais do que isso, estabelece o dispositivo ${ }^{6}$ que tais limites devem ser estabelecidos conjuntamente com os demais Poderes, o que é solenemente ignorado por praticamente todos os entes da Federação. Entre eles, está incluída a União, que os estabelece unilateralmente, sem qualquer consulta ou deliberação tomada de forma consensual, como exige expressamente a Constituição.

Não há como se negar a importância da independência do Poder Judiciário, do Ministério Público e da Defensoria Pública, para o que a autonomia financeira afigura-se como elemento indispensável. Permitir que os Poderes interfiram, por qualquer meio, uns nos outros, mitigando a sua independência, é ferir esta que, além de cláusula pétrea, configura um dos pilares nos quais se sustenta nosso Estado Democrático de Direito. Ao Poder Judiciário cabe tomar decisões sobre causas da maior relevância, muitas delas contrariando interesses de outros Poderes, ou mesmo de importantes e influentes membros dos Poderes da República. Nada mais atual do que ver o exemplo do chamado "mensalão", processo criminal cujas decisões finais estão sendo tomadas e resultará na prisão de políticos poderosos. Não há como conceber que o Poder Judiciário possa estar, nesta e em outras situações, subjugado pelos demais Poderes por qualquer razão, inclusive e especialmente

5 Conforme já argumentei em CONTI, José Mauricio. A Lei de Diretrizes Orçamentárias e a autonomia financeira do Poder Judiciário. Revista Forum de Direito Financeiro e EconômicoRFDFE, Porto Alegre, ed. Forum, ano 1, n. 1, mar./ago. 2012, p. 34.

6 Que, por sinal, como já registrado, é equivalente para o Ministério Público e Defensoria Pública, nos termos dos artigos já citados. 
financeira. Veja-se, neste mesmo caso, o papel do Ministério Público, a quem coube formular e sustentar a acusação contra os réus.

Há que se notar - e lamentar - o que tem ocorrido com o Poder Legislativo, muitas vezes constrangido pelo Poder Executivo a tomar medidas com as quais não está de pleno acordo, por pressões de natureza financeira a que fica submetido, como se tem visto na questão da liberação de recursos para as emendas parlamentares ao orçamento, assunto já abordado em duas colunas anteriores (Emendas ao orçamento e desequilíbrio de poderes, publicada em 3 de julho de 2012, e Orçamento impositivo é avanço para a administração, publicada em 7 de maio de 2013).

Há outras formas pelas quais se pode assegurar, ou melhorar, a autonomia financeira dos Poderes e instituições constitucionalmente independentes, tais como gerenciamento de fundos, participações previamente fixadas na receita orçamentária e vinculaçôes. E é também evidente que a autonomia financeira deve vir sempre e necessariamente acompanhada de boa gestão dos recursos, pois o que mais importa é usar bem o dinheiro público. Mas esses são assuntos para outras colunas. Respeitar as propostas orçamentárias apresentadas pelos Poder Judiciário, Ministérios Públicos e Defensorias Públicas já é um passo importante que os Poderes Executivos de toda a Federação podem dar para mostrar que estamos em Estado Democrático de Direito que cumpre sua Constituição. 